\section{SOI: $1.1 /$ TAS DOI: $10.15863 /$ TAS International Scientific Journal Theoretical \& Applied Science}

\author{
p-ISSN: 2308-4944 (print) e-ISSN: 2409-0085 (online) \\ Year: $2018 \quad$ Issue: $06 \quad$ Volume: 62
}

Published: $30.06 .2018 \quad$ http://T-Science.org

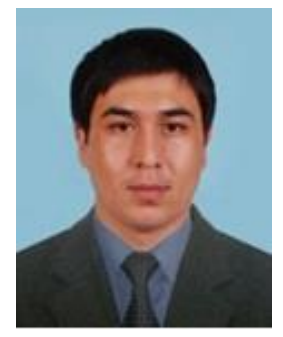

Sanjar Goyipnazarov

Researcher, Tashkent State University of Economics Tashkent, Uzbekistan

SECTION 31. Economic research, finance, innovation, risk management.

\title{
ASSESSMENT OF OCCUPATIONAL SAFETY MEASURES IN SMALL BUSINESSES
}

Abstract: The article in Namangan region of small business and private entrepreneurship in the country, employment, enterprises role in ensuring the well-being of the population and economic growth, labor protection measures being studied, analyzed and evaluated, as well as advice and suggestions for the improvement of the system. The development of small business and private entrepreneurship, special attention was given to expand the number of entrepreneurs, including high-tech, science is based on the most recent advances in technology and equipment to the country and to bring them to create appropriate conditions for the introduction of our primary duty is conditional on the it is possible to state the adequacy of recognition. Therefore, the development of the Republic of Uzbekistan for the period 2017-2021 the five priorities of the strategy of active entrepreneurial, innovative ideas and technologies to support the implementation of the Year of the state program to support entrepreneurship and business conditions outlined specific measures. The world of small business and private entrepreneurship in the field of labor protection, compensation and benefits costs savings, reduction in staff turnover, the level of labor productivity, the company provided an increase in the Fund's profitability and working hours. The analysis and scientific substantiation of labor protection in this area play an important role in the theory and practice of labor economics. Improving the scientific basis of protection of labor in small business entities will determine the prospects of socio-economic development in the sector and ensure the effectiveness of reforms implemented within the framework of the objectives of labor protection. This defines the relevance of the topic.

Key words: small business enterprises, safe working conditions for occupational safety, occupational injuries, occupational diseases, accidents.

Language: English

Citation: Goyipnazarov S (2018) ASSESSMENT OF OCCUPATIONAL SAFETY MEASURES IN SMALL BUSINESSES. ISJ Theoretical \& Applied Science, 06 (62): 207-212.

Soi: http://s-o-i.org/1.1/TAS-06-62-36 Doi: crossef https://dx.doi.org/10.15863/TAS.2018.06.62.36

\section{INTRODUCTION}

In recent years, there has been considerable difficulty in gaining effective employment worldwide. According to the United Nations (UN) and the International Labor Organization (ILO), global unemployment rate ranges from 170 million to 204 million in the period from 2007 to 2015. Experts estimate that by 2030 this figure will reach 470 million [1]. In 2015, the UN has hosted the World Summit on Sustainable Development with the participation of leaders from 150 countries. This Summit agenda included a new program that includes seventeen sustainable development goals. The main objective of the program was to promote sustainable economic growth through achieving high productivity levels by introducing innovative technologies.
The most successful way to achieve these goals lies in the creation of new jobs and the implementation of economic policies that encourage entrepreneurship. For this purpose set forth by the $\mathrm{UN}$, it is envisaged to provide full and productive employment for all, one of the main goals of decent work by 2030. As you know, small businesses and private entrepreneurship play an important role in ensuring employment worldwide. Many international organizations, including the United Nations and IOM, are working hard to support this sector. This sector has a high potential for creating new jobs and providing quantitative and qualitative employment. Today, this sector provides one-third of global employment [1]. 


\begin{tabular}{|c|c|c|c|c|c|c|}
\hline Impact Factor: & $\begin{array}{l}\text { ISRA (India) } \\
\text { ISI (Dubai, UAE } \\
\text { GIF (Australia) } \\
\text { JIF }\end{array}$ & $\begin{array}{l}=1.344 \\
=0.829 \\
=0.564 \\
=1.500\end{array}$ & $\begin{array}{l}\text { SIS (USA) } \\
\text { PИНЦ (Russia) } \\
\text { ESJI (KZ) } \\
\text { SJIF (Morocco) }\end{array}$ & $\begin{array}{l}=0.912 \\
=0.207 \\
=4.102 \\
=2.031\end{array}$ & $\begin{array}{l}\text { ICV (Poland) } \\
\text { PIF (India) } \\
\text { IBI (India) }\end{array}$ & $\begin{array}{l}=6.630 \\
=1.940 \\
=4.260\end{array}$ \\
\hline
\end{tabular}

\section{LITERATURE REVIEW}

Also scientists from CIS countries I.V.Gates [2], V.A.Devisilov [3], G.I.Belyakov [4], G.A.Vershina [5], O.S.Efremova [6], N.Karnaux [7], V.Korobko [8], R.Kouz [9], A.M.Lushnikov [10], Yu.M.Mihailov [11], Yu.Popov [12], O.M.Rodionova [13], V.Serduk [14] and others, theoretical and methodological bases of labor safety, production management, accident prevention, organization of workplace certification, labor conditions and labor productivity such as.

\section{ANALYZE AND RESULTS}

According to official statistics in Uzbekistan, 218,200 SMEs have been registered in 2017 by 2017 [15]. These subjects account for 57 per cent of the gross domestic product (GDP), 26.5 per cent of exports and almost 80 per cent of total employed in the economy [16]. These statistical data show that small business and private entrepreneurship play an important role in the employment of the country, the wellbeing of the population and the growth of the population. However, the vast majority of these types of business entities are incapable of endangering the environment at the earliest stages of their operations, with the effect of external environments [17].

In such a competitive environment, occupational safety plays an important role in maintaining long-term sustainability and sustainable development of small businesses. However, nowadays, many smaller enterprises use outdated techniques and technologies that do not meet today's requirements increase the risk of injury to employees. The state of the safety of small businesses is not at the level of demand. Employees are often not provided with special protective clothing, footwear or protective equipment from hazardous factors. Therefore, it is not surprising that small businesses suffer from double occupancy rates in state-owned enterprises [18].

Economically, work-related injuries, occupational diseases and accidents can also be averted by business entities because of the additional costs incurred by the employer [19]. Heads of small businesses believe that providing safe working conditions is costly, while insufficient safe working conditions can cost more.

Taking into account the abovementioned, surveys of some small business entities in Namangan region were conducted on the basis of surveys. This questionnaire was based on the Likert scale. The answer to this question is to answer the questions that are based on 5 parameters (dimensions): "5" - I strongly agree, I'm "4", "3" is not perfect, "2" does not fit, "1" I do not agree.

The research includes the following steps: organizational (preparation); the process of questionnaires; the results of processing are the stage of processing; making suggestions based on the results and making suggestions and recommendations for improvement of business activity.

The validity and reliability of the survey options based on the Likert scale are based on the assessment of its internal sustainability. To evaluate the internal consistency and internal consistency of the questionnaire, using the "IBM SPSS Statistics 22.0" program, the coefficient of "Alpha Kronbach" (Cronbach's alpha) was used.

$$
\alpha=\frac{N \cdot \bar{C}}{\bar{v}+(N-1) \cdot \bar{C}}
$$

Here:

$\alpha=$ Kronbach's alpha coefficient

$\mathrm{N}=$ Number of surveyed enterprises surveyed

$\overline{\mathrm{c}}=$ the average dependence of the results

$\overline{\mathrm{v}}=$ average difference.

Kronbach's alpha coefficient ranges from 0 to 1 if its value is $\alpha \geq 0.9$, then the internal sustainability of the results obtained from each question is "excellent" if " $\alpha \geq 0.8$ " is "good", if $\alpha \geq 0.7$, "acceptable" if a $\alpha \geq 0.6$, "suspicious", and finally if $\alpha \geq 0.5$, it is "inaccurate". In the study, it was found that this coefficient was 0.78 . This means that the statistical reliability of the survey is positive.

The demographic characteristics of the studied enterprises during the research process include the scope of their activities and the number of employees and the number of enterprises they have been operating for years.

The survey consisted of 30 small business subjects, 25 of them responded to the questionnaire. The remaining four did not answer the questionnaire, based on the internal policy of the business entities. 


\begin{tabular}{l|lr|ll|ll} 
& ISRA (India) & $=\mathbf{1 . 3 4 4}$ & SIS (USA) & $=\mathbf{0 . 9 1 2}$ & ICV (Poland) & $=\mathbf{6 . 6 3 0}$ \\
Impact Factor: & ISI (Dubai, UAE) $=\mathbf{0 . 8 2 9}$ & PUHЦ (Russia) $=\mathbf{0 . 2 0 7}$ & PIF (India) & $=\mathbf{1 . 9 4 0}$ \\
& GIF (Australia) & $\mathbf{0 . 5 6 4}$ & ESJI (KZ) & $=4.102$ & IBI (India) & $=\mathbf{4 . 2 6 0}$ \\
& JIF & $=\mathbf{1 . 5 0 0}$ & SJIF (Morocco) & $=\mathbf{2 . 0 3 1}$ & & \\
\hline
\end{tabular}

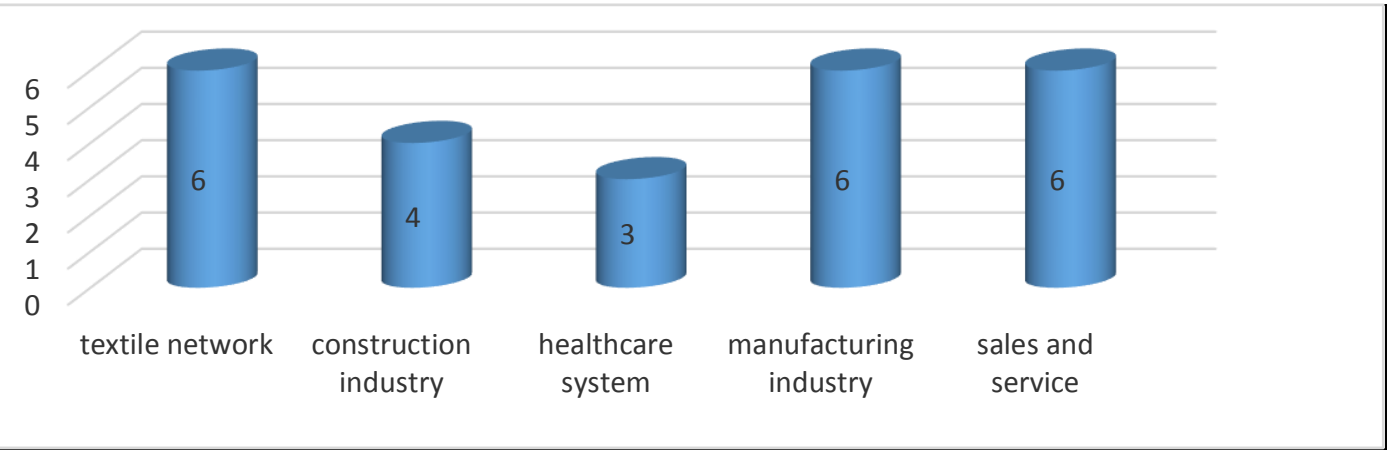

Source: Author's development

Picture 1. Distribution of small businesses by sectors and sectors studied during the survey.

As a result of statistical analysis, $6(24 \%)$ of 25 enterprises in the textile and light industry, $4(16 \%)$ in construction, $3(12 \%)$ in the healthcare system, 6 $(24 \%)$ in manufacturing, 24\%) in the sales and service sector. When analyzing the data received, it became clear that all the studied enterprises had a business history of at least five years. When analyzing the demographics of the surveyed enterprises, 6 of them were found to be from 5 to 10 , 8 to 11 to 25 , and to 11 to 26 to 50 .

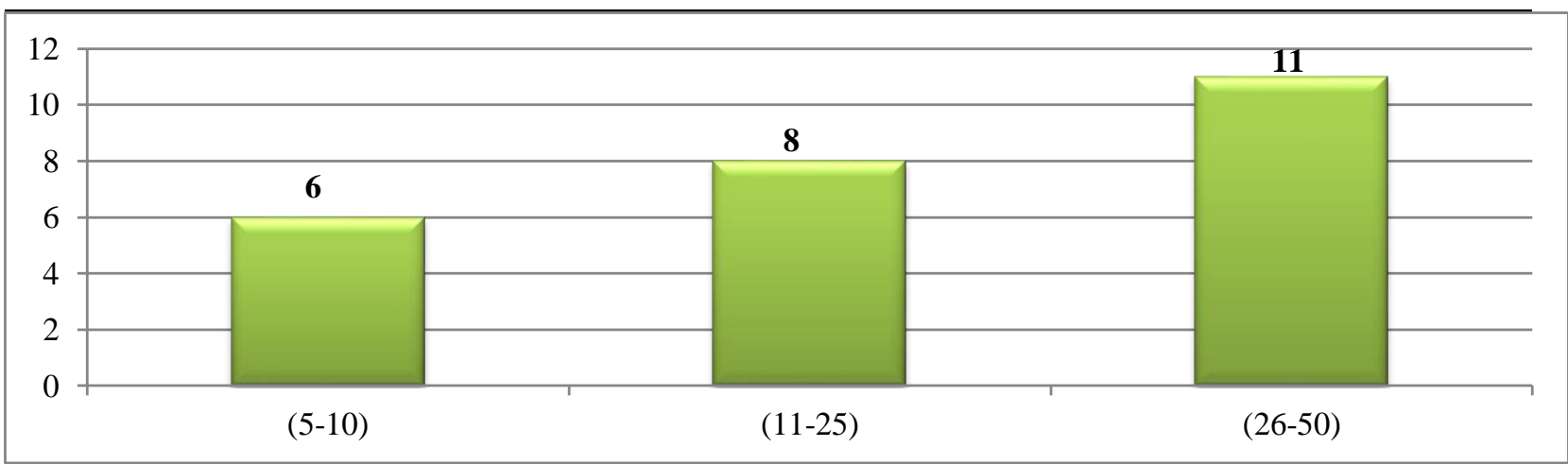

Source: Author's development

Picture 2. The classification of small businesses by the number of employees studied during the survey

Respondents' answers to the questionnaires were analyzed and their average statistical value and standard deviation were calculated. The results obtained in Table 1 show that the statistical value of the ventilation system in the workplace is $\bar{x}=4.04$ and
$\mathrm{SD}=0.53$. Here, as the $\overline{\mathrm{x}}$ have a statistical value of almost 4, the "Likert scale" responds to the claim that they are equipped with ventilation systems (Table 1). and the results are reflected.

\section{Implementation of occupational safety measures ${ }^{1}$}

\begin{tabular}{|l|l|c|c|}
\hline No & \multicolumn{1}{|c|}{ Measure of events } & $\begin{array}{c}\text { Average } \\
\text { statistical value } \\
(\mathbf{x})\end{array}$ & $\begin{array}{c}\text { Standard } \\
\text { deviation }\end{array}$ \\
\hline 1 & Ventilation system is installed in the workplace & 4,0400 & 0,53852 \\
\hline 2 & Enough coverage of workplaces is taken into account & 4,0000 & 0,50000 \\
\hline 3 & Workplaces are equipped with modern and safe technologies & 3,8000 & 0,57735 \\
\hline 4 & All workers are provided with personal protective equipment & 3,7600 & 0,52281 \\
\hline 5 & The company has a safety manual & 3,6800 & 0,62716 \\
\hline 6 & $\begin{array}{l}\text { The enterprise will be financially protected from occupational } \\
\text { healthcare activities }\end{array}$ & 3,3200 & 0,47610 \\
\hline 7 & The organization has enough information on labor protection & 3,3200 & 0,74833 \\
\hline
\end{tabular}

${ }^{1}$ Statistics obtained during the survey. 


\begin{tabular}{|l|l|c|c|}
\hline 8 & The workplace meets ergonomic requirements & 3,2800 & 0,61373 \\
\hline 9 & Employees have legal knowledge of labor protection & 3,2800 & 0,61373 \\
\hline 10 & $\begin{array}{l}\text { Employees of the enterprise are subject to medical examination in the } \\
\text { prescribed manner }\end{array}$ & 3,2400 & 0,77889 \\
\hline 11 & Employees are trained in labor protection & 2,9200 & 0,70238 \\
\hline 12 & Measures to prevent accidents are uninterrupted & 2,6800 & 0,55678 \\
\hline
\end{tabular}

Source: Information obtained by the author during the study

Failure to install ventilation system at work will result in contamination of the workplace and subsequent infectious diseases. Ventilation is one of the positive features of the physical working environment associated with the productivity of the workforce [20]. Also, the average statistical value of the responses received on issues of adequate coverage of the workplaces, safe operation of workplaces, provision of personnel with personal protective equipment, as well as availability of safety instructions in the enterprise. Therefore, the respondents said that they "agree" with these opinions.

The workplace lighting system is one of the most important elements in preventing accidents in production, staff health and safety, simplifying the working process, and increasing the workforce. Personal protective equipment protects employees from various harmful effects and extreme environment (extremely hot or cold) in the workplace. Misuse or misuse of personal protective equipment can lead to injury [21].

The company found that the average statistic value of the results of the workplace's compliance with the ergonomic requirements, the allocation of funds for the protection of labor, the medical examination of the staff in the prescribed manner and the right of employees to occupational safety were found. It is well-known that the researchers are convinced that they are not convinced of this. Responding to ergonomic requirements of the workplace can significantly reduce the level of hazard in production. Ergonomics should be part of the labor protection policy aimed at improving the working conditions of enterprises [22].

The average statistical value of the workforce for the training of employees on occupational safety training and prevention measures is close to $\bar{x}=2$. This means that according to the above method, the respondent does not agree with the implementation of such measures by the enterprises, which means that such measures are practically impossible at the enterprise. Training of employees on occupational safety plays an important role in the formation of security culture in the enterprise.

In practice, there are limited opportunities for the employer to fully fulfill all labor protection obligations in respect of the major business entities due to management and financial problems of small businesses. It is therefore difficult to fully adhere to the principle of unified compliance with the requirements of labor protection. It may be desirable to set a certain period of time for employers of small businesses to allow them to fully fulfill these requirements, and to allow gradual implementation of the measures envisaged.

Factors such as building a security culture, improving information delivery, increasing responsibility for employee health and safety, and ergonomic factors are more cost effective for the enterprise. Finally, research in Finland is remarkable. In this country, one of the existing laws and regulations on labor protection was found to be the most profitable for small businesses and some of them the most profitable (Table 2).

\section{Classification of occupational safety measures with regard to enterprise profitability}

Table 2

\begin{tabular}{|l|l|}
\hline \multicolumn{1}{|c|}{ What is profitable? } & \multicolumn{1}{|c|}{ What is not profitable? } \\
\hline $\begin{array}{l}\text { Important for enterprise activity: } \\
\text { - health and order; }\end{array}$ & $\begin{array}{l}\text { Technical modifications, disconnected from } \\
\text { other types of activities; } \\
\text { - Switchgear; } \\
\text { - organization of production, bringing raw materials and } \\
\text { materials to workplaces; } \\
\text { - improving the information delivery system; } \\
\text { - improving the business environment in the community. } \\
\text { - Chemical problems and pollination level } \\
\text { - noise level }\end{array}$ \\
\hline $\begin{array}{l}\text { Team membership accounting and staff participation in } \\
\text { enterprise management }\end{array}$ & The Ruler of the Supervisor and Entrepreneur \\
\hline $\begin{array}{l}\text { Responsibility for employee health and safety } \\
\text { Establish and maintain labor protection as } \\
\text { prescribed by law }\end{array}$ \\
\hline
\end{tabular}




\section{Impact Factor:}

\begin{tabular}{lr|lr} 
ISRA $($ India) & $=\mathbf{1 . 3 4 4}$ & SIS $($ USA) & $=\mathbf{0 . 9 1 2}$ \\
ISI $($ Dubai, UAE) & $=\mathbf{0 . 8 2 9}$ & PИНЩ (Russia) $=\mathbf{0 . 2 0 7}$ \\
GIF (Australia) & $=\mathbf{0 . 5 6 4}$ & ESJI (KZ) & $=\mathbf{4 . 1 0 2}$ \\
JIF & $=\mathbf{1 . 5 0 0}$ & SJIF $($ Morocco $)=\mathbf{2 . 0 3 1}$
\end{tabular}

$\begin{array}{ll}\text { ICV } \text { (Poland) } & =\mathbf{6 . 6 3 0} \\ \text { PIF (India) } & =\mathbf{1 . 9 4 0} \\ \text { IBI } \text { (India) } & =\mathbf{4 . 2 6 0}\end{array}$

\begin{tabular}{|l|l|}
\hline Analyzing problems and looking for reasons & $\begin{array}{l}\text { Requirements of technical decisions based on the } \\
\text { requirements of legislation and stand-by } \\
\text { requirements }\end{array}$ \\
\hline Planning Ergonomics and Engaging in Purchasing Equipment & $\begin{array}{l}\text { Ergonomics: } \\
\text { - Changes in individual workplaces without } \\
\text { taking into account the employment process }\end{array}$ \\
\hline $\begin{array}{l}\text { Medical service: } \\
\text { - Active work on the prevention and rehabilitation of the } \\
\text { company's medical center }\end{array}$ & $\begin{array}{l}\text { Medical service: } \\
\text { - Unlawful operation of the medical facility of } \\
\text { the enterprise; } \\
\text { - focus all attention on medical care }\end{array}$ \\
\hline
\end{tabular}

We believe that in the overall improvement of the work environment in the small business sector, it is important for employers of these businesses to reduce workplace costs and ensure the safety of technological processes in the workplaces rather than spending excessive costs for employee injuries and occupational diseases. . The employer should also be aware that the loss of work capacity as a result of disability or illness of an employee may result in more serious harm than the number of employees in a large number of enterprises.

\section{CONCLUSION}

Taking into account the above, experts believe that, with the involvement of trade unions, $86 \%$ of employees will be able to easily understand occupational hazards as a result of the training of workers. Labor-related casualties have a negative impact not only on human capital, but on the productivity of the enterprise. In addition, accidents can result in loss of power tools (technics) and loss of working days. Experts believe that job-related accidents may cause the company's competitiveness to decline, even in cases where its work is suspended.

The ente rprises studied in Namangan region pay special attention to the level of personal protection of employees, their safe and modern technologies, their safety instruction, and the provision of normal microclimate in the workplace. However, these enterprises are not paying much attention to the cost of labor protection, training of workers on occupational health and safety training, and prevention of accidents.

Sources:

(1).The President of the Republic of Uzbekistan Sh.Mirziyoev On the strategy of action for the further development of the Republic of Uzbekistan. February 7, 2017 PF-4947- number Decree // People's word February 8, 201728 (6722)- number.

\section{References:}

1. (2016) International Labor Office data, 2015; UN data, 2016.

2. Geitz I.V. (2013) Occupational Safety and Health. New requirements: A practical guide. M .: Dis, 2013. - 288 p .

3. Devisilov V.A. (2013) Occupational safety: Textbook. - Moscow: Forum, SIC INFRA-M, 2013. - 512 p .

4. Belyakov G.I. (2017) Occupational safety and health. Textbook. - Moscow: YURAYT, 2017. 406 .

5. Vershina GA (2014) Occupational safety: textbooks, manual. - Mn. : Information and Analytical Center of the Ministry of Finance, 2014. -487 p.
6. Efremova O.S. (2016) Labor protection from "A" to "I". - Moscow: Alfa-press, 2016. - 504 p.

7. Karnaukh N.N. (2017) Occupational Safety and Health. Textbook M.: YURAYT, 2017. - 382 p.

8. Korobko VI (2013) Labor protection: A manual for university students. - Moscow: UNITYDANA, 2013. - 239 p..

9. Coase R. (2001) Nature of the firm. / Ed., O.I. Williamson and S.J. Winter; Trans. with English. M.Ya. Kazhdana. - M.: The case, 2001. - 360 p.

10. Lushnikov A.M. (2015) Labor protection and labor legal control (supervision). Scientific and practical. - Moscow: Prospekt, 2015. - 248 p.

11. Mikhailov Yu.M. (2014) Industrial safety and labor protection. Directory of the head 


\begin{tabular}{|c|c|c|c|c|c|c|}
\hline Impact Factor: & $\begin{array}{l}\text { ISRA (India) } \\
\text { ISI (Dubai, UAE } \\
\text { GIF (Australia) } \\
\text { JIF }\end{array}$ & $\begin{array}{l}=1.344 \\
=0.829 \\
=0.564 \\
=1.500\end{array}$ & $\begin{array}{l}\text { SIS (USA) } \\
\text { PИНЦ (Russia) } \\
\text { ESJI (KZ) } \\
\text { SJIF (Morocco) }\end{array}$ & $\begin{array}{l}=0.912 \\
=0.207 \\
=4.102 \\
=2.031\end{array}$ & $\begin{array}{l}\text { ICV (Poland) } \\
\text { PIF (India) } \\
\text { IBI (India) }\end{array}$ & $\begin{array}{l}=6.630 \\
=1.940 \\
=4.260\end{array}$ \\
\hline
\end{tabular}

(specialist) of a hazardous production facility. Moscow: Alfa-Press, 2014. - 232 p .

12. Popov Yu.P. (2013) Labor protection / Yu.P. Popov. - Moscow: KnoRus, 2013. - 224 p .

13. Rodionova OM (2016) Medical and biological basis of safety. Occupational safety: A textbook for applied baccalaureate. - Lyubertsy: Yurayt, 2016. - $441 \mathrm{p}$.

14. Serdyuk VS (2016) Motivation to prevent accidents at work and occupational diseases: Textbook. allowance. - Omsk: Omsk State Technical University, 2016

15. (20218) https://stat.uz/uz/432-analiticheskiematerialy-uz/2031-o-zbekiston-respublikasidakichik-biznes-va-xususiy-tadbirkorlikningrivojlanishi

16. Silas Titus. (2015) Key Reasons Why Small Businesses Fail. Accredited Associate of The Institute for Independent Business. 2015. 9 p.

17. O.Abdurahmanov. (2010) Increasing effectiveness of management of labor protection system in the Republic of Uzbekistan. Monograph. "Fan" publishing house, 2010. P. 233

18. M.A.Gopang. (2015) Impact of Safety Management Practices on the Performance of SMEs. Thesis. Mehran University Pakistan. 2015. 137-156 p.

19. Ajala E.M. (2012) The influence of workplace environment on worker's welfare. Perform/ Product. 2012. 6-342.

20. Cavazza.N., Serpe A. (2009) Effects of safety norm violation exploring the mediating role of attitudal ambivalence toward personal protective equipment. J.saf. Res. 2009. 277283.

21. Veerle H., Jan V. (2006) The relation between $\mathrm{OSH}$ and ergonomics. Applied Ergonomics. Volume 37, Issue 4, July 2006, Pages 451-459.
22. Khoo. T.H., Lilis S. Mohd N.S. (2016) Safety training and safety behavior in the Malaysian SMEs. Journal of occupational safety and health. Volume 13. № 2. 2016.

23. Cagno E., Micheli.G., Jacinto C., Masi D. (2011) Occupational safety and health (OSH) performance of SMEs: a structural framework. International conference on industrial engineering and engineering management. 2011. p. 985-989.

24. Ekazheva, T.D. (2014) The process of risk management in a small enterprise / / Economics and Entrepreneurship, 2014, No. 5 Part 1 (461), p. 535-540.

25. Almus, M. (2004) The shadow of death - An Empirical Analysis of the Pre- Exit Performance of New German Firms. Small business Economics. - 2004. - 23 (3) - p. 192

26. Brunninge, O. (2000) SMEs in Strategic Networks, The Example of Swedish Entrepreneurs Re-organising Insurance Distribution, Paper presented at the RENT 14th Workshop in Prague, Nov 2000.

27. Fraser, J. (2010) Enterprise risk management, published by John Wiley and Sons, 2010. - p. 22-27.

28. (2014) MarketLine Industry Profile, Life Insurance in Sweden, January 2014, Available: http://www.marketline.com

29. Petrova M.S. (2007) Basics of production. Occupational Safety and Health. - Moscow: Academy, 2007. - 206 p.

30. Chubarova T. (2010) Health services in the workplace / / Man and work. - 2010. - №10. - P. $25-28$.

31. Shidlovskiy V. (2013) History of labor protection in Russia. / / Labor protection and social insurance. - 2013. - No. 4. - P.28-51. 